\title{
Does Male Circumcision Adversely Affect Sexual Sensation, Function, or Satisfaction? Critical Comment on Morris and Krieger (2013)
}

\author{
Gregory J. Boyle \\ Australian Institute of Psychology, Fortitude Valley, Queensland, Australia \\ Email: greg@aipc.net.au
}

Received 12 December 2014; accepted 24 March 2015; published 31 March 2015

Copyright (C) 2015 by author and Scientific Research Publishing Inc.

This work is licensed under the Creative Commons Attribution International License (CC BY). http://creativecommons.org/licenses/by/4.0/

(c) (i) Open Access

\begin{abstract}
Morris and Krieger (2013) have argued that male circumcision does not impact adversely on sexual sensation, satisfaction, and/or function. In the present paper, it is argued that such a view is untenable. By selectively citing Morris' own non-peer-reviewed letters and opinion pieces purporting to show flaws in studies reporting evidence of negative effects of circumcision, and by failing adequately to account for replies to these letters by the authors of the original research (and others), Morris and Krieger give an incomplete and misleading account of the available literature. Consequently, Morris and Krieger reach an implausible conclusion that is inconsistent with what is known about the anatomy and functions of the penile foreskin, and the likely effects of its surgical removal.
\end{abstract}

\section{Keywords}

\section{Circumcision, Sexual Dysfunction}

\section{Introduction}

Morris and Krieger's recent claim [1] that male circumcision has no adverse sexual effects misleads the reader. By downplaying empirical studies that have reported adverse sexual effects (often by selectively citing Morris' own non-peer-reviewed e-letters, and failing to mention or take into account others' critiques of those pieces), Morris and Krieger reach a conclusion that defies common sense. The foreskin itself is highly innervated erogenous tissue, which following amputation can no longer provide any sensory input to the brain [2]-[5]. Dur- 
ing intercourse, for example, the foreskin not only minimises chafing (common in circumcised men) [6] [7], but also provides erotogenic sensations as it glides back and forth over the glans, stimulating the latter structure and vice versa [8]. Clearly, any sexual activity involving the physical manipulation of the foreskin is necessarily lost to circumcision [9]. To claim then, as Morris and Krieger have, that "male circumcision has no adverse effect on sexual function, sensitivity, sexual sensation, or satisfaction," is to adopt rather limited definitions of those terms [9].

As Bossio et al. (2014) have recently stated, the paper by Morris and Krieger is "not a meta-analysis, thus, no statistical analyses of the data have been performed; instead, the article presents the authors' interpretation of trends” (p. 2854) [10] $]^{1}$. In giving such a subjective interpretation, however, Morris and Krieger misrepresent the information that is included in their own review. As Bossio et al. (2014, p. 2854) go on to state, “The conclusion they draw-that circumcision has no impact on sexual functioning, sensitivity, or sexual satisfaction-does not necessarily line up with the information presented in their review, which is mixed".

Morris and Krieger place undue reliance on methodologically flawed RCT studies in resource-poor African countries that have assessed sexual outcomes following adult, rather than infant circumcision, with measurements taken a maximum of 24 months after the surgery [11]. As Morris and Krieger report, at the 12-month time point, $99.7 \%$ of intact men (and 99.0\% of circumcised men) reported being "satisfied or very satisfied" with their sexual experience, changing to $99.9 \%$ and $98.4 \%$ at 24 months. But they fail to point out that these extremely high scores for sexual satisfaction are dramatically out of line with baseline estimates of sexual satisfaction in many other places in the world [12], and that the "rates of sexual dysfunction [reported in these studies] were 6 to 30 times lower than [those] reported in other countries," as noted by Van Howe (p. 20) [13]. Thus, it is either the case that Sub-Saharan Africans "are having the best sexual experiences on the planet" or the surveys used to assess sexual outcome variables in these studies were insensitive and flawed.

Consistent with the latter interpretation, Frisch has stated that, "Having obtained the questionnaires from the authors ... I am not surprised that these studies provided little evidence of a link between circumcision and various sexual difficulties. Several questions were too vague to capture possible differences between circumcised and not-yet circumcised participants (e.g. lack of a clear distinction between intercourse and masturbation-related sexual problems and no distinction between premature ejaculation and trouble or inability to reach orgasm). Thus, non-differential misclassification of sexual outcomes in these African trials probably favoured the null hypothesis of no difference, whether an association was truly present or not.” (p. 313) [14]

Morris and Krieger also misclassify a poor-quality study by Masters and Johnson from the 1960s as a highquality study, even though its methods were not adequately reported and its findings had been previously discredited [15], further skewing their "systematic review". ${ }^{2}$ In an empirical study $(N=163)$ of penile fine-touch pressure thresholds in circumcised versus genitally intact men, Sorrells et al. previously had reported that, “The finetouch sensitivity of 19 locations on the penis was measured using Semmes-Weinstein monofilament touch-test... When compared with the most sensitive area of the circumcised penis, several locations on the uncircumcised penis ... that are missing from the circumcised penis were significantly more sensitive.” (pp. 865-868) [15]. Morris and Krieger rate this study as "low quality" (that is, SIGN level 2-), without explaining how it meets their stated criteria of having a "high risk of confounding, bias, or chance and a significant risk that the relationship is not causal". The previous attempt by Morris to criticize this study in a letter to the editor co-authored with Waskett [16] betrayed a flawed understanding of the statistics involved-and was rebutted by Young [17]_but Morris and Krieger make no mention of this exchange.

Similarly, Morris and Krieger rate as "low quality" a study by Podnar, which compared elicitation of the penilo-cavernosus reflex among circumcised and genitally intact men [18]. Again, they do not provide adequate

\footnotetext{
${ }^{1}$ This has not stopped Morris from claiming that he published a "meta-analysis” when he only cites the calculations performed by Tian et al. (2013) [45]. In response to a letter to the editor Morris notes, "A recent methodologically impeccable systematic review and meta-analysis has established that MC has no adverse effect on male sexual function, sensitivity, or satisfaction” and cites his own review with Krieger, not the meta-analysis by Tian et al. (see Morris et al., 2014) [46]. Needless to say, referring to one’s own methodologically flawed review (as demonstrated herein) as "methodologically impeccable” is also misleading.

${ }^{2}$ In fact, the "study" by Masters and Johnson was not actually published as a study and never underwent peer-review. The results were mentioned in passing in one of their books without adequate clarification of the methodology used in making the comparisons. To rate such a source as "high quality", then, suggests that it is not so much the actual rigor of study design that weighed most heavily in Morris and Krieger's categorization decisions, but more the reported results of the study. Specifically, studies with results that appear consistent with Morris and Krieger's conclusion that circumcision does not have adverse effects on sexuality are rated as being of relative "high quality", while studies with results that are inconsistent with this conclusion are rated by Morris and Krieger as being of relative "low quality", at least partially independent of the actual quality of the methodologies in question.
} 
justification for their decision to rate the study as "low quality". While the penilo-cavernosus reflex was elicited in $92 \%$ of genitally intact men, it could only be elicited in $27 \%$ of circumcised men, providing strong evidence of a significant diminution ( $\mathrm{p}<0.001$ ) in sexual function in circumcised as compared with intact men. Podnar further reported (p. 582) that, "It is known that [the] foreskin, but not glans penis, contains a high density of penile fine-touch mechanoreceptors. Clinically the penilo-cavernosus reflex provides information on function of the sacral nerve... in the majority of circumcised men this reflex cannot be elicited clinically." It seems arguable that the quality assigned to a study by Morris and Krieger reflects a study's results more than the methodology used (see second footnote).

Michetti et al. (2006) reported increased alexithymia (a personality trait disorder associated with difficulty in emotional identification and expression) among men with ED problems [19]. In addition, in an empirical survey of alexithymia among circumcised versus genitally intact males $(N=300)$, Bollinger and Van Howe (p. 184) reported that circumcised men were, “4.53 times more likely to use an erectile dysfunction drug” than genitally intact men [20]. In their attempt to dismiss the relevance of this study, Morris and Krieger note that ED drugs can be used recreationally — which may well be true-but this would not explain the observed difference in the use of such drugs between the circumcised and intact men in this study.

In an online survey ( $N=1369$ ), Bronselaer et al. (p. 820) [21] found that, "For the glans penis, circumcised men reported decreased sexual pleasure and lower orgasm intensity. They also stated more effort was required to achieve orgasm, and a higher percentage of them experienced unusual sensations (burning, prickling, itching, or tingling and numbness of the glans penis). For the penile shaft a higher percentage of circumcised men described discomfort and pain, numbness and unusual sensations... Our study confirms the importance of the foreskin for penile sensitivity, overall sexual satisfaction, and penile functioning." While Morris and Krieger attempt to downplay the relevance of this large sample study by citing their own opinion-based letter to the editor critiquing it [22], they do not so much as acknowledge the reply by Bronselaer [23], which pointed out the multiple flaws in their critique.

More recent studies published subsequent to the Morris and Krieger opinion piece, do not support their interpretation of the literature. For example, Dias et al. (p. 122) [24] reported that following adult circumcision, "there was an increase in frequency of erectile dysfunction (9.7\% versus $25.8 \%, \mathrm{p}=0.002)$ and delayed orgasm (11.3\% versus 48.4\%, p < 0.001)". While acknowledging that there are a number of factors involved in the etiology of erectile dysfunction (ED), it is unlikely to be a coincidence that in circumcising cultures such as the USA, 52\% of middle-aged men suffer from varying degrees of erectile dysfunction, whereas in non-circumcising cultures such as Germany, the prevalence is only 19\% (see Wespes et al., p. 4) [25]. They also reported (p. 32 ) that the highest prevalence of premature ejaculation (PE) is found in the USA (31\%) where circumcision is common, whereas in France (a non-circumcising culture), the lifetime prevalence is only 15\%, suggesting that circumcision itself may be a causal determinant of premature ejaculation.

Indeed, Bollinger and Van Howe [20] also found that circumcised men are 2.56 times more likely than genitally intact men, to suffer from premature ejaculation (cf. Tang \& Khoo) [26]. At least 10 studies have been published comparing PE prevalence in genitally intact versus circumcised men [24] [27]-[35]. A meta-analysis based on all 10 studies found a trend that circumcised men were more likely to suffer from premature ejaculation (OR = 1.15; 0.93 to 1.41) [36]. As Boyle [37] commented, "Is it not more likely that it is precisely the lack of neurological control over the timing of ejaculation resulting from the severed neuronal circuitry after circumcision that is a major causal factor in PE?”

It is informative to note that Morris fails to disclose his close affiliation with the Circumcision Academy of Australia (see http://www.circumcisionaustralia.org/), whose inaugural President-C. Terry Russell—appears to derive a personal income from performing circumcisions (see http://www.circumcision.net.au), but does not report this as conflict of interest in his articles co-authored with Morris. Morris has also published materials with the pro-circumcision advocacy group, The Gilgal Society, further undermining his claim to have "no conflict of interest”. In reality, Morris is a highly-active circumcision lobbyist-see

http://web.archive.org/web/20110518091029/http://www.circinfo.net/pdfs/GFW-EN.pdf

The surgical removal of anatomically normal, healthy erogenous tissue from infant males is unlikely to have no adverse consequences; in the case of girls, such procedures are illegal. Any form of non-therapeutic, nonconsensual cutting into the female genitalia, regardless of what kind or how much tissue is or is not removed, regardless of how expertly the surgery is performed, and regardless of whether one could find any health benefits for doing it (such research is of course not legal to carry out), is defined by law as an impermissible violation 
of the girl's right to bodily integrity. Neonatal male circumcision remains a sexually harmful procedure [6] [7]

[38]-[43], and Morris and Krieger's "systematic review" does little to alter that reality [44].

\section{References}

[1] Morris, B.J. and Krieger, J.N. (2013) Does Male Circumcision Affect Sexual Function, Sensitivity, or Satisfaction? A Systematic Review. The Journal of Sexual Medicine, 10, 2644-2657.

[2] Cold, C.J. and Taylor, J.R. (1999) The Prepuce. BJU International, 83, 34-44. http://dx.doi.org/10.1046/j.1464-410x.1999.0830s1034.x

[3] Taylor, J.R. (2007) Fine-Touch Pressure Thresholds in the Adult Penis. BJU International, 100, 218. http://dx.doi.org/10.1111/j.1464-410X.2007.07026_4.X

[4] Taylor, J.R. (2007) The Forgotten Foreskin and Its Ridged Band. The Journal of Sexual Medicine, 4, 1516. http://dx.doi.org/10.1111/j.1743-6109.2007.00588.x

[5] Taylor, J.R., Lockwood, A.P. and Taylor, A.J. (1996) The Prepuce: Specialized Mucosa of the Penis and Its Loss to Circumcision. British Journal of Urology, 77, 291-295. http://dx.doi.org/10.1046/j.1464-410X.1996.85023.x

[6] Bensley, G.A. and Boyle, G.J. (2001) Physical, Sexual, and Psychological Impact of Male Infant Circumcision: An Exploratory Survey. In: Denniston, G.C., Hodges, F.M. and Milos, M.F., Eds., Understanding Circumcision: A MultiDisciplinary Approach to a Multi-Dimensional Problem, Kluwer Academic/Plenum, New York, 207-239.

[7] Bensley, G.A. and Boyle, G.J. (2003) Effects of Male Circumcision on Female Arousal and Orgasm. The New Zealand Medical Journal, 116, 595-596.

http://www.nzma.org.nz/_data/assets/pdf_file/0010/17974/Vol-116-No-1181-12-September-2003.pdf

[8] Scott, S. (1999) The Anatomy and Physiology of the Human Prepuce. In: Denniston, G.C., Hodges, F.M. and Milos, M.F., Eds., Male and Female Circumcision: Medical, Legal, and Ethical Considerations in Pediatric Practice, Kluwer Academic/Plenum, New York, 9-18.

[9] Earp, B.D. (2015) Sex and Circumcision. American Journal of Bioethics, 15, 43-45. http://dx.doi.org/10.1080/15265161.2014.991000

[10] Bossio, J.A., Pukall, C.F. and Steele, S. (2014) A Review of the Current State of the Male Circumcision Literature. The Journal of Sexual Medicine, 11, 2847-2864. http://dx.doi.org/10.1111/jsm.12703

[11] Boyle, G.J. and Hill, G. (2011) Sub-Saharan African Randomised Clinical Trials into Male Circumcision and HIV Transmission: Methodological, Ethical and Legal Concerns. Journal of Law and Medicine, 19, 316-334.

[12] Mulhall, J., King, R., Glina, S. and Hvidsten, K. (2008) Importance of and Satisfaction with Sex among Men and Women Worldwide: Results of the Global Better Sex Survey. The Journal of Sexual Medicine, 5, 788-795. http://dx.doi.org/10.1111/j.1743-6109.2007.00765.x

[13] Van Howe, R.S. (2015) A CDC-Requested, Evidence-Based Critique of the Centers for Disease Control and Prevention 2014 Draft on Male Circumcision: How Ideology and Selective Science Lead to Superficial, Culturally-Biased Recommendations by the CDC.

https://www.academia.edu/10553782/A_CDC-requested_Evidence-based_Critique_of_the_Centers_for_Disease_Cont rol and Prevention 2014 Draft on Male Circumcision How Ideology and Selective Science Lead to Superficial _Culturally-biased_Recommendations_by_the_CDC

[14] Frisch, M. (2012) Author's Response to: Does Sexual Function Survey in Denmark Offer Any Support for Male Circumcision Having an Adverse Effect? International Journal of Epidemiology, 41, 312-314. http://dx.doi.org/10.1093/ije/dyr181

[15] Sorrells, M.L., Snyder, J.L., Reiss, M.D., et al. (2007) Fine-Touch Pressure Thresholds in the Adult Penis. British Journal of Urology International, 99, 864-869.

[16] Waskett, J.H. and Morris, B.J. (2007) Fine-Touch Pressure Thresholds in the Adult Penis. British Journal of Urology International, 99, 1551-1552. http://dx.doi.org/10.1111/j.1464-410X.2007.06970_6.X

[17] Young, H. (2007) Fine-Touch Pressure Thresholds in the Adult Penis. British Journal of Urology International, 100, 699.

[18] Podnar, S. (2011) Clinical Elicitation of the Penilo-Cavernosus Reflex in Circumcised Men. British Journal of Urology International, 109, 582-585.

[19] Michetti, P.M., Rossi, R., Bonanno, D., et al. (2006) Male Sexuality and Regulation of Emotions: A Study on the Association between Alexithymia and Erectile Dysfunction (ED). International Journal of Impotence Research, 18, 170174. http://dx.doi.org/10.1038/sj.ijir.3901386

[20] Bollinger, D. and Van Howe, R.S. (2011) Alexithymia and Circumcision Trauma: A Preliminary Investigation. International Journal of Men's Health, 10, 184-195. http://dx.doi.org/10.3149/jmh.1002.184 
[21] Bronselaer, G.A., Schober, J.M., Meyer-Bahlburg, H.F., T’Sjoen, G., Vlietinck, R. and Hoebeke, P.B. (2013) Male Circumcision Decreases Penile Sensitivity as Measured in a Large Cohort. British Journal of Urology International, 111, 820-827.

[22] Morris, B.J., Krieger, J.N. and Kigozi, G. (2013) Male Circumcision Decreases Penile Sensitivity as Measured in a Large Cohort. British Journal of Urology International, 111, E269-E270.

[23] Bronselaer, G. (2013) Reply. British Journal of Urology International, 111, E270-E271. http://dx.doi.org/10.1111/bju.12128_10

[24] Dias, J., Freitas, R., Amorim, R., et al. (2014) Adult Circumcision and Male Sexual Health: A Retrospective Analysis. Andrologia, 46, 459-464. http://dx.doi.org/10.1111/and.12101

[25] Wespes, E., Eardley, I., Giuliano, F., et al. (2013) Guidelines on Male Sexual Dysfunction: Erectile Dysfunction and Premature Ejaculation. European Association of Urology, EAU. http://www.guideline.gov/content.aspx?id=45322

[26] Tang, W.S. and Khoo, E.M. (2011) Prevalence and Correlates of Premature Ejaculation in a Primary Care Setting: A Preliminary Cross-Sectional Study. The Journal of Sexual Medicine, 8, 2071-2078. http://dx.doi.org/10.1111/j.1743-6109.2011.02280.x

[27] Laumann, E.O., Masi, C.M. and Zuckerman, E.W. (1997) Circumcision in the United States: Prevalence, Prophylactic Effects, and Sexual Practice. The Journal of the American Medical Association, 277, 1052-1057. http://dx.doi.org/10.1001/jama.1997.03540370042034

[28] Masood, S., Patel, H.R.H., Himpson, R.C., et al. (2005) Penile Sensitivity and Sexual Satisfaction after Circumcision: Are We Informing Men Correctly? Urologia Internationalis, 75, 62-66. http://dx.doi.org/10.1159/000085930

[29] Richters, J., Smith, A.M.A., de Visser, R.O., et al. (2006) Circumcision in Australia: Prevalence and Effects on Sexual Health. International Journal of STD AIDS, 17, 547-554. http://dx.doi.org/10.1258/095646206778145730

[30] Ferris, J.A., Richters, J., Pitts, M.K., et al. (2010) Circumcision in Australia: Further Evidence on Its Effect on Sexual Health and Wellbeing. Australian and New Zealand Journal of Public Health, 34, 160-164.

[31] Son, H., Song, S.H., Kim, S.W. and Paick, J.S. (2010) Self-Reported Premature Ejaculation Prevalence and Characteristics in Korean Young Males: Community-Based Data from an Internet Survey. Journal of Andrology, 31, 540-546. http://dx.doi.org/10.2164/jandrol.110.010355

[32] Frisch, M., Lindholm, M. and Grønbæk, M. (2011) Male Circumcision and Sexual Function in Men and Women: A Survey-Based, Cross-Sectional Study in Denmark. International Journal of Epidemiology, 40, 1367-1381. http://dx.doi.org/10.1093/ije/dyr104

[33] Shaeer, O. (2013) The Global Online Sexuality Survey (GOSS): The United States of America in 2011 Chapter III-Premature Ejaculation among English-Speaking Male Internet Users. The Journal of Sexual Medicine, 10, 18821888. http://dx.doi.org/10.1111/jsm.12187

[34] Krieger, J.N., Mehta, S.D., Bailey, R.C., et al. (2008) Adult Male Circumcision: Effects on Sexual Function and Sexual Satisfaction in Kisumu, Kenya. The Journal of Sexual Medicine, 5, 2610-2622. http://dx.doi.org/10.1111/j.1743-6109.2008.00979.x

[35] Frisch, M., Lindholm, M. and Grønbæk, M. (2011) Male Circumcision and Sexual Function in Men and Women: A Survey-Based, Cross-Sectional Study in Denmark. International Journal of Epidemiology, 40, 1367-1381. http://dx.doi.org/10.1093/ije/dyr104

[36] Van Howe, R.S. (2014) Meta-Analysis of 10 Studies Comparing Premature Ejaculation Prevalence in Genitally Intact versus Circumcised Men. Personal Communication, 5 July 2014, in Preparation.

[37] Boyle, G.J. (2012) Clinical Elicitation of the Penilo-Cavernosus Reflex in Circumcised Men. British Journal of Urology International, 110, E150.

[38] O’Hara, K. and O’Hara, J. (1999) The Effect of Male Circumcision on the Sexual Enjoyment of the Female Partner. British Journal of Urology International, 83, 79-84.

[39] Hammond, T. (1999) A Preliminary Poll of Men Circumcised in Infancy or Childhood. British Journal of Urology International, 83, 85-92. http://dx.doi.org/10.1046/j.1464-410x.1999.0830s1085.x http://onlinelibrary.wiley.com/doi/10.1046/j.1464-410x.1999.0830s1085.x/abstract;jsessionid=41315F127ED7263B95 3C41E5E41C4686.f03t01

[40] Boyle, G.J., Goldman, R., Svoboda, J.S. and Fernandez, E. (2002) Male Circumcision: Pain, Trauma and Psychosexual Sequelae. Journal of Health Psychology, 7, 329-343. http://dx.doi.org/10.1177/135910530200700310

[41] Goldman, R. (1997) Circumcision: The Hidden Trauma. Vanguard, Boston.

[42] Goldman, R. (1999) The Psychological Impact of Circumcision. British Journal of Urology International, 83, 93-103.

[43] Kim, D. and Pang, M.G. (2006) The Effect of Male Circumcision on Sexuality. British Journal of Urology International, 99, 619-622. 
[44] Earp, B.D. and Darby, R. (2015) Does Science Support Infant Circumcision? A Skeptical Reply to Brian Morris. The Skeptic. https://www.academia.edu/9872471/Does_science_support_infant_circumcision

[45] Tian, Y., Liu, W., Wang, J.-Z., et al. (2013) Effect of Circumcision on Male Sexual Functions: A Systematic Review and Meta-Analysis. Asian Journal of Andrology, 15, 662-666. http://dx.doi.org/10.1038/aja.2013.47

[46] Morris, B.J., Bailis, S.A. and Wiswell, T.E. (2014) In Reply_Bias and Male Circumcision. Mayo Clinic Proceedings, 89, 1588-1589. http://dx.doi.org/10.1016/j.mayocp.2014.09.002 